EGU2020-20044

https://doi.org/10.5194/egusphere-egu2020-20044

EGU General Assembly 2020

(c) Author(s) 2021. This work is distributed under

the Creative Commons Attribution 4.0 License.

\title{
A reconstruction of paleoenvironments and climate change during the Late Holocene in Sierra Nevada: the organic and inorganic geochemistry record from the Borreguil de los Lavaderos de la Reina record (southern Iberian Peninsula)
}

\author{
Alejandro J. López-Avilés ${ }^{1}$, Antonio García-Alix ${ }^{1,2}$, Gonzalo Jiménez-Moreno ${ }^{1}$, Jaime L. Toney ${ }^{3}$, and \\ R. Scott Anderson ${ }^{4}$ \\ ${ }^{1}$ University of Granada , Estratigrafía y Paleontología, Spain (lopezaviles@ugr.es) \\ ${ }^{2}$ Instituto Andaluz de Ciencias de la Tierra (IACT), Centro Superior de Investigaciones Científicas-Universidad de Granada \\ (CSIC-UGR), Granada, Spain \\ ${ }^{3}$ School of Geographical and Earth Sciences, University of Glasgow, UK \\ ${ }^{4}$ School of Earth and Sustainability, Northern Arizona University, USA
}

Remote small alpine lakes and wetlands from the Sierra Nevada mountain range (southern Spain) are exceptional ecological sensors of global change and preserve a complete post-glacial Holocene sedimentary record. Several organic and inorganic geochemical analyses carried out in the sedimentary record of the Borreguil de los Lavaderos de la Reina, a small bog located in the north face of the Sierra Nevada at $2421 \mathrm{~m}$, have allowed us to reconstruct climate, vegetation and human interaction in the highest mountain range in southern lberia in the last 3000 years. This study shows that during the Late Holocene there is a progressive climatic aridification, which produced a reduction in the aquatic environments in Sierra Nevada. The studied peat bog geomorphology and surrounding areas also conditioned the evolution of the local vegetation. An increasing trend in the detrital eolian input from northern Africa, as well as an important anthropic impact in the ecosystems (artificial drainage system among other activities) are observed in the studied record in the last century. 